\title{
Savage Gardens, Original Sins: An Anarcho-Primitivist Reading of Wagner's Parsifal
}

\begin{abstract}
By Lisa Burnett ${ }^{*}$
Imaginings of a lost Eden often feature humanity in harmony with the natural world, but should that natural world be a garden - tame, gentle, harmless - or untouched wilderness? For anarchoprimitivists, the answer is clear. Popularized by contemporary writers such as Jared Diamond, Daniel Quinn, and John Zerzan, the anarcho-primitivist movement holds that humankind's decision to cultivate the earth many millennia ago ultimately led to the host of modern societal ills it faces today, including socio-economic inequality, hierarchical power structures, plague and communicable disease, and environmental degradation. Though it has grabbed headlines in recent years, anarcho-primitivism can in fact trace its history to ancient Greek and Indian thought and the Judeo-Christian Book of Genesis, via Rousseau's noble savage and a variety of nineteenth century environmental, intellectual, and health reform movements. Entwined with these last three we find Richard Wagner's final opera, Parsifal (1883), known for its lush music and cryptic message, and frequently associated with the composer's exploration of contemporary political and social ideas in western Europe, including racial theory, theosophy, and vegetarianism. The opera's fundamental contrast, in music and text, lies between the villainous Klingsor, the cultivator of an enchanted garden of flower maidens, and the virtuous Grail knights, who leave their land as pristine wilderness and depend for sustenance on what is provided by the Holy Spirit. This paper examines the musical and textual portrayal of nature in Parsifal in the context of the larger anarchoprimitivist movement in Western culture, which itself broadly encompasses many of the ideologies that so captivated its composer.
\end{abstract}

If one had to sum up anarcho-primitivism in a bumper-sticker-length catchphrase, it might be "leave the earth alone." The movement's devotees are an eclectic bunch, with a variety of diverse positions among them, but they share a common core of rejection of modern civilization, and the belief that food cultivation - i.e. the Neolithic revolution some 10,000 years ago - is at the root of the social inequities and environmental problems seen as plaguing contemporary man. Humans should, instead, subsist on whatever nature

${ }^{*}$ PhD Candidate, Stanford University, USA. 
provides, without attempting to interfere in the process in any way. In the words of John Zerzan, one of anarcho-primitivism's leading advocates, it is the "will to dominate animals and plants" that is civilization's "defining basis." The movement has, of late, experienced something of a flowering in both science and popular culture. Anarcho-primitivism forms the basis of a series of best-selling novels by author Daniel Quinn, in which agricultural societies are characterized as "Takers," their model of living harmful and unsustainable, in contrast to the forager societies of "Leavers," who live in balance with the natural world. ${ }^{2}$ Intellectuals and academics have contributed to the discussion as well, with such heavyweights as anthropologist Jared Diamond opining provocatively that the decision to cultivate the earth was "the worst mistake in the history of humanity."3 Expanding on his thesis with a flair at times more literary than scientific, Diamond couches his account of the "mistake" in the language of Biblical temptation and perdition. "Just imagine a band of savages, exhausted from searching for nuts or chasing wild animals, suddenly grazing for the first time at a fruit-laden orchard or a pasture full of sheep," he writes. "[S]educed by the transient abundance they enjoyed until population growth caught up with increased food production," of course they would want to adopt agriculture, only to discover later that "with [it] came the gross social and sexual inequality, the disease and despotism, that curse our existence."4

For a position that is initially striking, if not shocking, in its radicality, anarcho-primitivism has been able to marshal a fair amount of evidence in its favor. The raising of crops and livestock led humans to form permanent settlements with the accumulation of material possessions - perhaps the initial catalyst for today's consumerist society. Settled villages with material accoutrements could lead to crowding, and its concomitant evils of crime and communicable diseases. Contagion, however, is not the only consequence of the switch from foraging to cultivation; examination of ancient skeletons has revealed that agricultural peoples, at least initially, were shorter, weaker-boned, more likely to be malnourished, and more often suffered from maladies such as celiac disease and dental cavities than their forager cousins. The shift to an agricultural way of life introduced the concept of land ownership to humanity, leading to unequal power relationships between landlords and tenants, and an unbalanced distribution of societal resources - the first division of humanity into "haves" and "have-nots." Finally, abandoning foraging in favor of food production undeniably produced a population boom (often estimated on the order of tenfold or more), which could lead to environmental degradation and the loss of native wildlife habitats. ${ }^{5}$ If one is looking for an arrow to sling at a

\footnotetext{
${ }^{1}$ John Zerzan, Twilight of the Machines (Port Townsend, WA: Feral House Publishing, 2008). 52-53.

${ }^{2}$ Ishmael, originally published in 1992, is the first and best-known of these. Daniel Quinn, Ishmael (New York: Bantam, 1992).

3ared Diamond, "The Worst Mistake in the History of the Human Race," Discover Magazine May 1987: 67.

${ }^{4}$ Ibid. 68, 66.

${ }^{5}$ These findings in and of themselves (as opposed to their potential sociopolitical implications) are relatively uncontroversial and can be found in standard college anthropology textbooks.
} 
modernity thought to be overly materialistic, unequal, and exploitative of the earth, that provided by anarcho-primitivism would seem squarely to hit the mark.

It is important to note that for anarcho-primitivists, it is not necessarily that agriculture per se is bad, but the "will to dominate" (whether the target of domination be plants, animals, or other humans) and the consequences wrought by it listed above - i.e., anarcho-primitivism's real target is not farming in and of itself, but modern civilization and the perceived havoc it has wreaked on human and environmental health. The movement is notoriously light on solutions, with proposals ranging from a vaguely conceived "more ethical" form of cultivation to universal adoption of vegetarianism to a wholescale return to a hunter-gatherer lifestyle. While perhaps appealing on ethical or ideological grounds, such arrangements have no precedent in human history and are likely not feasible on any sustained or large-scale basis, a fact readily admitted by at least a few of the movement's champions. Zerzan himself acknowledged in an interview that, while anarcho-primitivism had "great, grandiose ideas," at the moment it did not have "blueprints for what people should do," and was more of a protest movement. ${ }^{1}$ His statement suggests that anarcho-primitivism, like many environmentalist movements, has more than bare science at its core; in fact, skepticism or outright suspicion of man's "will to dominate animals and plants" has strong roots in well-established and ancient Western literary and cultural narratives.

The idea of a lost golden age where humans did not cultivate plants or animals, and in which backbreaking labor, inequity, and even death were subdued or absent has a long and storied past predating modern environmentalist concerns by two millennia or more. Perhaps the most famous example is the story of the Fall of Man in Genesis 2-3, in which originally Adam and Eve subsist solely on fruits, seeds, and herbs. ${ }^{2}$ Being cast out of Eden brings both farming and death all in a single verse. ${ }^{3}$ Already here the practices of farming and meat-eating are linked together as hallmarks of a postlapsarian world.

The Classical Greeks reached a similar conclusion through slightly different logic. Pythagoras and his followers advocated vegetarianism based on the doctrine of transmigration of souls - perhaps a forerunner of the modern animal rights movement - and believed that in the (now lost) Golden Age, humans and animals were nonviolent and could communicate with each other. In other words, "[h] $\mathrm{h}$ umans were not kings or lords of everything that moved."

See, for instance, Emily A. Schultz and Robert H. Lavenda, Anthropology: A Perspective on the Human Condition, $2^{\text {nd }}$ ed. (Mountain View, CA: Mayfield Publishing Company, 2000). 196-200.

${ }^{1}$ Duncan Campbell, “Anarchy in The USA," The Guardian 17 April 2001 (online edition, http://www.guardian.co.uk/world/2001/apr/18/mayday.features11, accessed 3/15/13).

${ }^{2}$ Genesis 1:29-30 (King James Version).

3 "[I] in the sweat of thy face shalt thou eat bread, till thou return unto the ground; for out of it wast thou taken: for dust thou art, and unto dust shalt thou return."Genesis 3:19 (King James Version).

${ }^{4}$ Colin Spencer, Vegetarianism (New York and London: Four Walls Eight Windows, 2002), 54. 
Though harboring no overt suspicions of agriculture, there is some evidence that Pythagoras "desired his disciples to be able to sustain themselves on easily gathered raw foods and the purest water." Other ancient movements that sought to liberate followers from the mundane routines of crop cultivation and animal husbandry characteristic of modern, "civilized" life included the Bacchic religions ${ }^{2}$ and the Orphic sects. ${ }^{3}$

This line of thinking persisted throughout the middle ages, but was bolstered in the late eighteenth and early nineteenth centuries by an infusion of ideas from the nascent fields of anthropology and environmental science. Rousseau's famous description of the "noble savage" was but one of many attempts to characterize the lifestyles of indigenous hunter-gatherer peoples as evidence for the purportedly lost human ideal. ${ }^{4}$ Reactions to the environmental and social consequences of industrialization played a role in bolstering anarcho-primitivist modes of thought as well, as Europe's cities began to grow polluted from factory waste and increasingly teemed with underclasses of factory laborers suffering from various health and nutritional maladies. ${ }^{5}$

These paved the way for a spate of reform movements built on the anarcho-primitivist foundation provided by ancient Classical and JudeoChristian writings and aimed at bringing modern people back into harmony with each other and their surroundings and thus improving the health of both the population and the environment. Such pursuits were particularly popular in Germany. ${ }^{6}$ Grouped under the catch-all term Lebensreform, their component constituencies, in line with anarcho-primitivism's lack of adherence to any particular set of practical solutions, encompassed such seemingly disparate causes as temperance, anti-vivisectionism, nudism, vegetarianism, and various strains of anarchism and socialism. Though not all Lebensreform proponents took an explicit position on food cultivation, elements of anarcho-primitivist pervaded the movement. Attempting to write the comprehensive summation of all things Lebensreform at the end of the century, Adolph Just was quite explicit on the abhorrence of agriculture and its consequences, marshalling in

\footnotetext{
${ }^{1}$ Ibid. 53.

${ }^{2}$ Quoted in ibid., 56.

${ }^{3}$ Ibid. 56-57.

${ }^{4}$ Such a view is suggested by Rousseau's Discourse on Inequality, where the author identifies "savage" tribes as living in a "third state" that is neither identical to the "state of nature" nor as far from it as members of European civilization. He also associates agriculture with the rise of social and economic inequality as well as various health problems, making him one of the first Western authors to do so. Rousseau himself, however, disavowed primitivism in favor of a faith in the progress of modern peoples toward a more fair and egalitarian social compact. Jean-Jacques Rousseau, A Discourse Upon the Origin and the Foundation of Inequality Among Mankind (1755), trans. uncredited (Fordham University Internet History Sourcebooks, http://www.fordham.edu/halsall/mod/1782rousseau-inequal.asp, accessed 3/16/13).

${ }^{5}$ Spencer 237-250.

${ }^{6} \mathrm{Nyhart}$ attributes this to the confluence of concerns about the "unhealthy, unnatural influences influences of [industrial] urban life" with the particular drive toward political unity and nationhood that gripped the German-speaking lands at the time. Lynn K. Nyhart, Modern Nature: The Rise of the Biological Perspective in Germany (Chicago: University of Chicago Press, 2009), 3.
} 
support of his argument the works of Jesus and Goethe, as well as a hodgepodge of claims from the fields of chemistry, sociology, and human and veterinary medicine. The following passages are illustrative.

The field mark formerly appeared like a garden... with its interspersed hedges and trees, and green meadows; but to-day it makes a most uninspiring and dreary impression. [It] is no longer pleasing and refreshing. All this, even the cruelty against the animals, has come about because the land owners wished to make more money out of agriculture and stock-raising. For this reason, too, all sorts of artificial, chemical fertilizers, and innumerable machines have been invented and introduced. ... But rarely can it be shown more clearly than here that all striving and struggling for earthly mammon strictly speaking leads but to misery and poverty. ... Yes, the rich farmer of to-day is in truth very poor.

The old Germans... in the beginning allowed nature to provide for them entirely with her nuts and other fruit. When the Germans began the CHASE (the FALL OF MAN), which was soon followed by the use of alcohol and other unnatural practices, they deteriorated and became more and more brutalized, and finally developed into an enervated and miserable race just like the rest of the civilized nations.... ${ }^{2}$

In Germany, therefore, "just like the rest of the civilized nations," the drive to dominate animals and plants - characterized literally as "the fall of man" - is thought not only to have ruined the beauty of the once-pristine "field mark," but to be at the root of social and economic inequality, exploitative labor practices, health problems, and the outright "deterioration" of the population.

Into this cultural milieu stepped Richard Wagner, who took no unambiguous position on cultivation in and of itself, but did write extensively on certain Lebensreform ideas, and displayed thinking concordant with anarcho-primitivist critiques of civilization, particularly toward the end of his life leading up to the composition of his final opera. Jost Hermand observes:

[Wagner's] anticivilizationist hatred for the beast in man was even stronger [than], and partially superseded his anti-Semitism. Especially in the second half of the 1870s, Wagner stated again and again that humankind had been depraved, degenerate, and rotten since ancient times. He pinpointed the time of "original sin" as the transition of man from a gatherer of fruits and berries...to the

\footnotetext{
${ }^{1}$ Adolph Just, Return to Nature! Paradise Regained, English edition trans. Benedict Lust (New York: Benedict Lust, 1903), 247.

${ }^{2}$ Ibid. 249-50, capitalization in original. Interestingly, Just does support limited cultivation of fruits and nuts, as long as the cultivation practices are "natural" and not too invasive, though he is lacking in details on this last point.
} 
carnivorous beast of prey. Wagner had long been fascinated by a "green utopia..."

Hermand's focus is Wagner's support for the vegetarian and antivivisectionist movements, and he convincingly shows that the views conveyed on these subjects in Wagner's writings from the late 1870s and early 1880s find their way into the Parsifal libretto. I argue, however, that underlying Wagner's advocacy of vegetarianism in these writings are subtle elements of the anarcho-primitivist thought handed down in Western culture for two millennia, and that these elements may be seen even more clearly to percolate through the text and music of the composer's final opera.

The relevant Wagnerian writings are the open letter to Ernst Weber (1879), and two of the "regeneration essays," Religion and Art and its supplement, To what use this knowledge? (both 1880). Though concerned with the relatively narrow topic of killing animals, the letter to Weber evinces a belief that man's domination of animals is a type of original sin that led to physical and mental health problems in the population:

[W] hen first it dawned on human wisdom that the same thing breathed in animals as in mankind, it appeared too late to avert the curse which,... we seemed to have called down upon us through the taste of animal food: disease and misery of every kind, to which we did not see vegetable-eating men exposed. ${ }^{2}$

The belief in the sentience of animals has much in common with Pythagorean thought (in which Wagner was well aware), while the linking of man as predator with "disease and misery" is decidedly nineteenth century. In Religion and Art, however, Wagner delves further into the logic behind his view of humanity and its need for regeneration:

...[W]e may take it for granted that the birth and earliest dwellingplace of the human species may be set in countries warm and clad with ample vegetation. ...At the first dawning of history we believe we find the aborigines of the present Indian peninsula in the cooler valleys of the Himalayan highlands, supporting themselves as graziers and tillers of the soil...a smiling Nature offered them with willing hand its varied products; fed without care, an earnest contemplation would lead them to profound reflection on that former world wherein they had learnt the stress of need and bitter toil, ay, of strife and warfare for possession. ${ }^{3}$

\footnotetext{
${ }^{1}$ Jost Hermand, "Wagner's Last Supper: The Vegetarian Gospel of his Parsifal," in Re-reading Wagner, ed. Reinhold Grimm and Jost Hermand (Madison, WI: University of Wisconsin Press, 1993), 107.

${ }^{2}$ Richard Wagner, Richard Wagner's Prose Works, trans. William Ashton Ellis, vol. 6 (London: Routledge, 1897), 202.

${ }^{3}$ Ibid. 227.
} 
On the surface, Wagner seems to accept both farming and herding in this passage, but on closer examination, he also seems to think that not too much human effort should be involved in these pursuits. Before the fall, places where people lived were already amply supplied with food by "Nature," who fed them without arduous labor on their part. For mere vegetarian advocacy, whether on health or animal rights grounds, this line of "evidence" isn't particularly necessary. What the passage does do, however, is underscore the importance of the drive for domination, for conquest ("strife and warfare") first of animals, then of each other, to the "fallen" status of modern human civilization (from which the aboriginal peoples in the above passage are supposed to have learned it). "Attack and defence, want and war, victory and defeat, lordship and thraldom, all sealed with the seal of blood: this from henceforth is the History of Man," elaborates Wagner, tracing this history from ancient Greece to modern Europe. "All our states are founded on conquest and the subjugation of earlier inhabitants, and the latest conqueror has always taken the land and soil as hereditament." 2 The solutions to these problems, per To What Use this Knowledge?, are to be found through striving for "regeneration," largely through art but also with assistance from physiology, politics, and economics. Wagner is characteristically foggy on precise steps to take in this direction - an opaqueness not uncommon in anarcho-primitivist thinking more generally. He closes with an exhortation to readers to take the following oath:

We recognise the cause of the fall of Historic Man, and the necessity of his regeneration; we believe in the possibility of such Regeneration, and devote ourselves to its carrying-through in every sense. $^{3}$

Thus, underlying Wagner's promotion of vegetarianism lies a deep-seated skepticism of man's dominance of other men, of animals, and to some extent the earth itself, and a drive to reverse the corrupt state of modern society through a reachievement of the natural, healthy state of affairs - all tenets of anarcho-primitivism.

The influence of anarcho-primitivist thought comes through even more strongly in Parsifal, Wagner's operatic tale of an innocent fool who retrieves the lost sacred spear from a wizard named Klingsor and returns it to the knights of the Holy Grail, in the process bringing redemption to their wounded and fallen king. While Parsifal is a work that often seems to have as many interpretations as there are listeners, infused as it is with, inter alia, sundry themes of sex and sin, perdition and redemption, nineteenth century racial and scientific theories, elements of anarcho-primitivist thought can be discerned in its text and music via the characterization of opera's two chief opposing camps:

\footnotetext{
${ }^{1}$ Ibid.

${ }^{2}$ Ibid. 234.

${ }^{3}$ Ibid. 262.
} 
the Grail knights and Klingsor and his minions. ${ }^{1}$ The former are depicted as living in a type of harmony with nature that leaves the latter untouched and pristine, whereas Klingsor is shown as having exerted dominance over his environment in a way that has exacted, and continues to exact, terrible costs.

The most conspicuously anarcho-primitivist characteristic of the knights of the Grail realm is that they are supposed to receive their sustenance from the Grail itself, rather than from any earthly source - a conflation of the concepts of physical and spiritual nourishment already present in Wolfram von Eschenbach's medieval epic. ${ }^{2}$ That the knights do not hunt or raise livestock is made clear from Kundry's "Sind die Tiere hier nicht heilig?" and the episode following Parsifal's shooting of the swan in Act I, but rather more surprising are the indications that they do not cultivate plant foods either, something a monastic community would normally be expected to do and a feature whose absence implies that there is more at work here than vegetarianism alone. In Act I, we learn of Gawan's travels to collect (impliedly medicinal) herbs, and, more tellingly, in Act III Gurnemanz reveals that since Amfortas has refused to perform the Grail ceremony any longer, the knights have been reduced to relying on ordinary food for sustenance, gathering herbs and plants in the woods as they had learned from animals. The knights do not seem to take any measures whatsoever to disturb the woods and meadows in which they live, referring to wildflowers "watered with tears from sinners,"3 rather than any effort or duty on their part. As long as they adhere to this regimen, they are able to stay healthy and live on indefinitely. ${ }^{4}$ Nor is there any hint of a striving for material possessions among them; they are shown as living simply and having few, if any, personal belongings. The Grail and the Spear belong collectively to the order, with Titurel and later Amfortas as their lead caretakers as opposed to their owners.

Wagner's characterization of the Grail realm and its inhabitants also lacks a strong sense of fixity of physical location. We hear in Acts I and III of the knights frequently traveling far and wide with messages, to assist in crusades, or to gather herbs. Monsalvat itself is evidently difficult to find ${ }^{5}$ and Parsifal has trouble returning to it after having successfully retaken the Spear from Klingsor at the end of Act II. There is also Gurnemanz's famously cryptic pronouncement "Zum Raum wird hier die Zeit," further suggesting that Monsalvat is not a point on a map, but the place where the Grail's servants

\footnotetext{
${ }^{1}$ The status of Kundry and Parsifal, the two characters who are known to move somewhat freely between the Grail realm and Klingsor's castle, is somewhat more ambiguous both in relation to anarcho-primitivism and more generally, and so is set aside from the bulk of the present analysis.

${ }^{2}$ E.g. Gurnemanz's "denn bist du rein/wird nun der Gral dich tränken und speisen,” from Act I, Scene 2. In Wolfram's poem the Grail acts as a sort of cornucopia delivering physical food to its spiritual devotees.

${ }^{3}$ In Act III, Parsifal even explicitly contrasts these wildflowers with their very cultivated counterparts in Klingsor's realm, with the preference clearly given to the former.

${ }^{4}$ Even when forced to rely on wild plants and herbs, they are still able to achieve a very long lifespan. For example, Gurnemanz is described as "zum hohen Greise gealtert" by the beginning of Act III.

${ }^{5}$ Gurnemanz describes its location at the ends of "Pfaden die kein Sünder findet,"
} 
come together in spiritual devotion, whose physical location could theoretically vary. Ulrike Kienzle, taking a cue from Wagner's apparent hedging in his stage directions as to the physical location of Monsalvat, ${ }^{1}$ has referred to it as resembling the "center of an imaginary universe," comparing its function in the opera to that of a far off peak or distant star to ancient peoples - something to be gazed at, perhaps even worshipped, from afar, but not actually within reach. ${ }^{2}$ This sort of yearning for Monsalvat through space might be compared to the way members of modern civilization could yearn - through time - for a lost Eden: ephemeral, ever unreachable, and yet always there in the distance as an ideal to be striven for. This conception of place is also somewhat more in line with non-agricultural, "pre-civilization" human modes of living, where permanent settlement of a specific physical location was not primary, and thus could be concordant in another way with the lost golden age to which anarchoprimitivism harkens.

Wagner's depiction of Klingsor and his minions contrasts sharply with the harmonious simplicity evinced by the Grail realm, and carries with it many of the indicia of the corruption that civilization brings. Klingsor, most notably, clearly does cultivate the land around him, transforming what was originally a desert into a rapturous garden filled with enchanting flower maidens. ${ }^{3}$ These he also "harvests" 4 as though they are a combination of plants and livestock - or, in Kienzle's formulation, plants and women, in a twisted mix of Schopenhauerian plant innocence and human sentience. ${ }^{5}$ Unlike Amfortas in the Grail realm, Klingsor is explicitly shown as having a master/slave relationship with Kundry, and an exploitative one with the flower maidens. He also has a bevy of shiny material possessions. ${ }^{6}$ He has no objections to the killing or maiming of other living things, as shown by his exhortation "Ho! Ihr Wächter! Ho! Ihr Ritter" and what follows in Act II. Even so, he is still consumed with envy of the Grail knights, desiring to possess first the Spear entrusted to them, and ultimately the Grail itself. The location of his castle also seems fairly strongly fixed ${ }^{7}$ and he is never described as leaving or having left it - rather, it is the knights who come to him. ${ }^{8}$ Perhaps most importantly,

\footnotetext{
1“'Gegend im charakter der Nördlichen Gebirge des Gotischen Spaniens," emphasis added.

${ }^{2}$ Ulrike Kienzle, "Die heilige Topografie in Wagners Parsifal," Wagnerspectrum IV(1) (2008), 72 .

${ }^{33}$ "Die Wüste schuf er sich zum Wonnegarten/drin wachsen teuflisch holde Frauen." Interestingly, however, what Klingsor does for sustenance is never specified. His garden and its inhabitants have purposes other than nourishment.

4“im Lenz pflückt uns der Meister"

${ }^{5}$ Kienzle, Das Weltüberwindungswerk: Wagners 'Parsifal' - ein szenisch-musikalisches Gleichnis der Philosophie Arthur Schopenhauers (Laaber: Laaber Verlag, 1992), 101 and ff.

${ }^{6}$ Wagner's stage directions for the beginning of Act II specify that Klingsor be surrounded by tools of necromancy and sorcery, and a silver mirror.

${ }^{7}$ E.g. he is described as being "Jenseits im Tale."

${ }^{8}$ The "hedging" in Wagner's stage directions with respect to the physicality of Monsalvat also seems to have disappeared or at least been muted, providing a stronger link between Klingsor's realm and that of ordinary (implicitly fallen, heathen) people than that found in the Grail realm. ("Klingsors Zauberschloss - am Südabhang derselben Gebirge, dem arabischen Spanien zugewandt").
} 
though, Klingsor and his realm are depicted as both unhealthy and unholy. In order to obtain the ability to create his magical workings, Klingsor had to make a horrible personal sacrifice - self-castration - that took him out of harmony with God and nature and allowed him to actively subvert them both with sorcery. It is significant that Amfortas loses both his physical and spiritual health after succumbing to temptation in Klingsor's garden, a fate not unlike that of "primitive" peoples who spend time in "civilized" lands. One might even recall here Jared Diamond's description of the fruit-laden orchards that once tempted "bands of savages" with their "seductive blessings" - and all the consequences that followed.

The contrast in the relationship each set of characters has with the natural world also plays out in the way pastoral music is treated and distributed between them. For the two acts that take place in the Grail realm, Wagner writes music that is immediately identifiable as pastoral, both in light of his own previous ventures in that genre, and the larger tradition of pastoral music more generally. Here, for example, is what is usually called the "Waldrauschen" or "Waldesmorgenpracht" motif, which forms the backbone of the scenes in the woods in Act I:

Figure 1. 'Waldesmorgenpracht' Motif

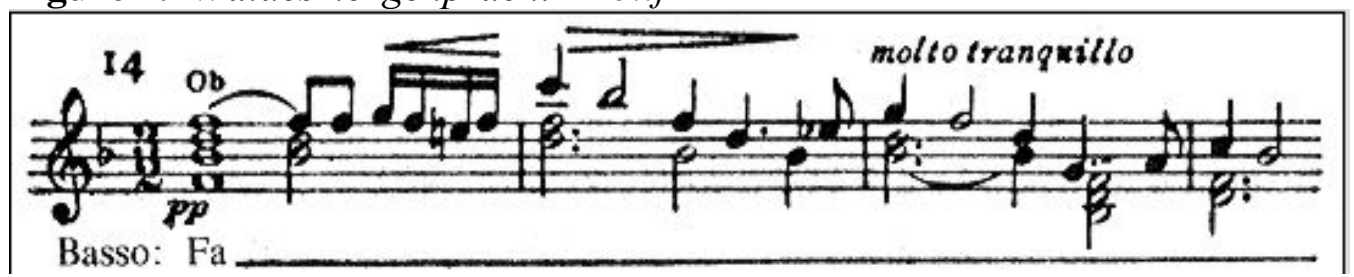

Here one can see several textbook elements of pastoral music: major mode, an emphasis on intervals of the triad, a bass line pedal, and woodwind lines that evoke bird calls. ${ }^{1}$ The excerpt also fits with Wagner's existing pastoral style, characterized by a texture that balances slow wavering figures in the strings with a woodwind line that seems to grow organically from the diatonic scale, in similar fashion to the Waldweben from Siegfried or even Siegmund's "Winterstürme wichen dem Wonnemond" from Die Walküre.

The Good Friday music in Act III, tonally stable in B major and unfolding gradually through the use of a ritornello-like formal structure, follows a similar template, though infused with elements of religious solemnity appropriate to the occasion in the libretto (a slower tempo and a processional character generated by a sense of meter far stronger than anything hitherto heard in the third act):

\footnotetext{
${ }^{1}$ Geoffrey Chew and Owen Jander, "Pastoral," Grove Music Online, ed. L. Macy (www.oxfordmusiconline.com, accessed 3/16/13).
} 
Figure 2. Good Friday Music
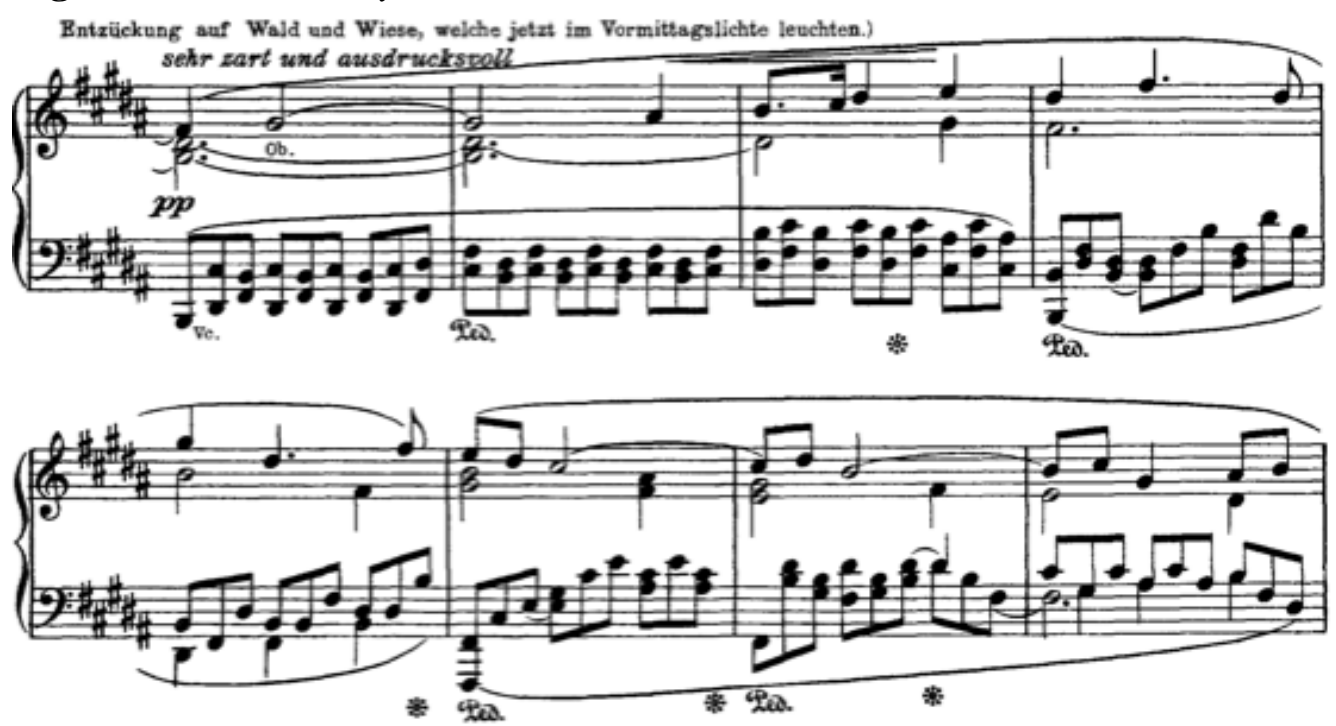

Friedrich Oberkogler described the Good Friday music as growing organically out of the main motivic materials of the work as a whole, so that it would seem to originate from them and yet contain them all at the same time, symbolic of the redemption that comes to man and nature alike during the passage. $^{1}$

Turning to Act II and Klingsor's domain, it is not obvious that there should be nature music at all, unnatural as he and his surroundings are. The entire act takes place within the confines of his magic castle and the gardens that sit nestled within outer ramparts, rather than in any sort of open countryside. Yet nature music there is, though of a starkly different character than that associated with the Grail realm. Even before the curtain goes up, the turbulent prelude seems to indicate that nature in this context is neither holy nor benign. Cast in B minor (the musical antithesis of the Good Friday music's B major, perhaps) and featuring swirling melodic figures and crashing diminished seventh chords over an unrelenting tremolo in the low strings, it bears the hallmarks of a musical storm, not unlike the one that opens Die Walküre. Though Wagner's score and stage directions never explicitly characterize the prelude as stormy, more than one commentator has heard it this way, including Hans von Wolzogen, who described not only the prelude but the entire scene that follows in colorful language evoking a storm unleashed from the depths of hell. ${ }^{2}$

The opera's better-known instance of nature music comes during Parsifal's encounter with the Flower Maidens in Act II, Scene 2. Despite having many of

\footnotetext{
${ }^{1}$ Friedrich Oberkogler, Parsifal: Der Zukunftsweg des Menschen in Wagners Musikdrama (Stuttgart: Freiesgeistesleben, 1983), 176.

${ }^{2}$ Hans von Wolzogen, Thematischer Leitfaden durch die Musik des Parsifal, $4^{\text {th }}$ ed. (Leipzig: Senf, 1882), 40 and ff. The author also once encountered a pocket edition of the score to which an unknown editor had helpfully added the indication Stürmisch bewegt above the first entrance of Klingsor's motif in the prelude.
} 
the textbook characteristics of a pastoral, including a triadic melody, triple meter, prominent woodwind lines filled with trills and turns, and occasionally a drone bass, it somehow sounds a universe apart from the pure pastoral scenes of Acts I and III. One might be tempted to point a finger at an effort on Wagner's part at exoticism - after all, the scene is supposed to take place somewhere in the southern, Moorish, portion of Spain - but upon closer examination, there is little in the music that is particularly exotic; the scene is in a relatively uncomplicated A-flat major and filled with triadic sonorities. Theodor Adorno heard adumbrations of the Jugendstil here, but attempts to find real exoticism, whether Arab or otherwise, have borne little fruit. ${ }^{1}$ The sources of the scene's oddness of sound lie elsewhere. Though largely diatonic, the scene is rather unstable tonally, replete with unresolved dominant seventh and ninth chords that hover, shimmering, in the air, and constantly gesturing at the flat-VI and eventually flat-II scale degrees, as though unsure whether to settle on the sharp or flat side of the circle of fifths. The ever-so-vaguely "Arabesque" descending vocal lineis composed of whole-tone intervals that divide the octave symmetrically and obscure the sense of a tonal center. The foursquare-ish triple meter forms a stark contrast to the rest of the opera - a valse lente in a work with decidedly the wrong context for such a thing, and the material is presented in static blocks; it does not grow and develop organically in the manner of the "Waldesmorgenpracht" motif or the Good Friday music, and similarly lacks the murmuring strings or germinal woodwind line that both of those excerpts possess. The timbre of the scene is also unusual, with a sudden influx of female voices where they had hitherto been rare or absent, and the dominance of the treble register over the bass, certainly unusual in this opera and for Wagner in general.

The overall effect of the nature music deployed in both sections of Act II discussed above is to suggest the lack of a solid foundation for Klingsor's realm. This has sometimes been read to mean that Klingsor's castle and the Flower Maidens are nothing but an illusion, a reading bolstered by Parsifal's bewildered "dies alles hab' ich nun geträumt?" but belied by the physical nature of the interactions among the flower maidens, the fallen knights, and Parsifal himself. Parsifal is described as slaying some of the fallen knights in combat - taking Ferris's sword, for example - and it is implied that the flower maidens are able to touch him physically. ${ }^{2}$ As such, I would suggest that the products of Klingsor's sorcery are not unreal but temporary, a deceptive burst of fleeting abundance purchased at too high of a cost to be maintained. Put in modern environmentalist parlance, one could say that Klingsor's relationship with nature is unsustainable.

"At the beginning of domination and repression, the start of the long process of depleting the riches of the living world, is a very ill-advised

\footnotetext{
${ }^{1}$ Theodor W. Adorno, "Zur Partitur des 'Parsifal," in Moments Musicaux (Frankfurt: Suhrkamp, 1964), 56.

${ }^{2}$ As demonstrated in the flower maidens' exclamations, "Mir schlug er den Liebsten...Noch blutet die Waffe!;” and "Lass mich die Wange dir fühlen/den Mund lass mich dir küssen!".
} 
separation from the flow of life."1 These words were penned by John Zerzan in 2008 , but they could just as easily have been written two hundred or two thousand years ago. It seems that part and parcel with human manipulation of the natural world and the exertion of dominance over its plants and animals is the sense that something significant has been lost. Perhaps this is why "civilized" peoples have for so long been drawn to anarcho-primitivist thinking, with its promises of a return to, or rebirth of, a simpler time, where humans would live in harmony with each other and with nature, none master over the others. The acuteness of such longing could only have been heightened by the advent of industrialization in the nineteenth century, explaining how such an idea can seem so quintessentially Romantic despite its lifespan dwarfing that of the actual Romantic era. Wagner's Parsifal weaves together several of the threads of anarcho-primitivist thought in its overall narrative of sin, perdition, and redemption, holding out the promise of some sort of utopia as the curtain comes down on Act III. But is it a restorative, backward-glancing utopia, or a progressive, forward-looking one? Wagner himself seems to have thought the latter, but, as Kienzle points out in the closing paragraphs of her book, the overall impression left by the opera is ambiguous on this question. ${ }^{2}$ I would suggest, though, that the answer is simultaneously "both" and "neither," for what anarcho-primitivists dream of is a future that, somehow, will put human beings back into the "flow of life," rectifying that long-ago mistake that has since wrought so much misery upon the world.

\section{References}

Adorno, Theodor W. "Zur Partitur des 'Parsifal," in Moments Musicaux. Frankfurt: Suhrkamp, 1964. 52-57.

Campbell, Duncan. "Anarchy in the USA," The Guardian 17 April 2001. Online edition, $\quad$ http://www.guardian.co.uk/world/2001/apr/18/mayday.features11, accessed 3/15/13.

Chew, Geoffrey and Owen Jander. "Pastoral," Grove Music Online, ed. L. Macy. www.oxfordmusiconline.com, accessed 3/16/13.

Diamond, Jared. "The Worst Mistake in the History of the Human Race," Discover Magazine May 1987: 66-68.

Just, Adolph. Return to Nature! Paradise Regained, English edition trans. Benedict Lust. New York: Benedict Lust, 1903.

Hermand, Jost. "Wagner's Last Supper: The Vegetarian Gospel of his Parsifal," in Re-reading Wagner, ed. Jost Hermand and Reinhold Grimm. Madison, WI: University of Wisconsin Press, 1993. 103-118.

Kienzle, Ulrike. "Die heilige Topografie in Wagners Parsifal," Wagnerspectrum IV(1) (2008): 69-90.

\footnotetext{
${ }^{1}$ Zerzan 4.

${ }^{2}$ Wagner quotation and analysis found in Kienzle, Das Weltüberwindungswerk, 230.
} 
Das Weltüberwindungswerk: Wagners 'Parsifal' - ein szenischmusikalisches Gleichnis der Philosophie Arthur Schopenhauers. Laaber: Laaber Verlag, 1992.

Nyhart, Lynn K. Modern Nature: The Rise of the Biological Perspective in Germany. Chicago: University of Chicago Press, 2009.

Oberkogler, Friedrich. Parsifal: Der Zukunftsweg des Menschen in Wagners Musikdrama. Stuttgart: Freiesgeistesleben, 1983.

Quinn, Daniel. Ishmael. New York: Bantam, 1992.

Rousseau, Jean-Jacques. A Discourse Upon the Origin and the Foundation of Inequality Among Mankind (1755), trans. uncredited. Fordham University Internet History Sourcebooks, http://www.fordham.edu/halsall/mod/1782rous seau-ine qual.asp, accessed 3/16/13.

Schultz, Emily A. and Robert H. Lavenda. Anthropology: A Perspective on the Human Condition, $2^{\text {nd }}$ ed. Mountain View, CA: Mayfield Publishing, 2000.

Spencer, Colin. Vegetarianism. New York and London: Four Walls Eight Windows, 2002.

Taylor, Bron. Dark Green Religion. Berkeley and Los Angeles: University of California Press, 2010.

Wagner, Richard. Prose Works, in 10 vols., ed. William Ashton Ellis. London: Routledge, 1897.

Wolzogen, Hans von. Thematisches Leitfaden durch die Musik des Parsifal, $4^{\text {th }}$ ed. Leipzig: Gebrüder Senf, 1882.

Zerzan, John. Twilight of the Machines. Port Townsend, WA: Feral House Publishing, 2008. 